\title{
Marcus Antonius Orator and his quaestors: positions of imperium bearer and the order of lower magistrates' service under him
}

V. V. Dementyeva ${ }^{1}$

${ }^{1}$ P. G. Demidov Yaroslavl State University, 14 Sovetskaya str., Yaroslavl 150003, Russian Federation

DOI: $10.18255 / 1996-5648-2021-3-306-319$

Research article Full text in Russian

The article examines controversial questions about what positions Marcus Antonius Orator held in 102-100 BC and in what order were the quaestors Caius Norbanus and Aulus Gabinius under him as the bearer of the imperium. The following historical reconstruction is proposed: sent in $102 \mathrm{BC}$ in the position of praetor to Cilicia to fight pirates, M. Antonius continued his mission in $101 \mathrm{BC}$ in the status of proconsul of the province of Asia. The Greek designation for the office

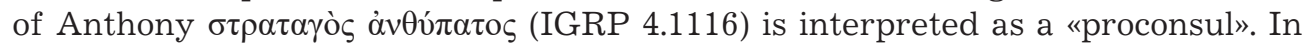
the same $101 \mathrm{BC}$ to him, the governor of Asia, Aulus Gabinius arrived as a quaestor (and not in $102 \mathrm{BC}$, as is often stated in historiography), who, most likely, remained with him in the status of proquestor for the 100th year. It doesn't not look possible for the author to determine the year of questorship of C. Norbanus under M. Antonius and assumptions in the scientific literature about 102, 101, 100 and 99 BC years are rejected in the article. According to the author, the questorship of Norbanus occurred some year earlier than $103 \mathrm{BC}$; at the same time dating to $113 \mathrm{BC}$ is practically excluded. There are more reasons to believe that in the chronological period from the pro-praetorian powers of M. Antonius in 113 to his mission in Cilicia he was endowed with an empire in some year and had C. Norbanus as a quaestor, but due to the «silence» of the sources, it is not possible to establish this year.

Keywords: praetor; proconsul; quaestorship; imperium; pro praetore; pro consule;

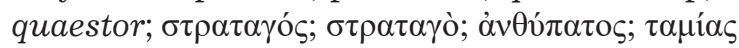

\section{INFORMATION ABOUT AUTHORS}

\begin{tabular}{l|l} 
Dementyeva, Vera V. & $\begin{array}{l}\text { E-mail:vv_dementieva@mail.ru } \\
\text { Doc. Sc. (History), Professor, Head of The Scientific } \\
\text { \& Educational Centre for Classical Studies }\end{array}$
\end{tabular}




\title{
Марк Антоний Оратор и его квесторы: должности носителя империя \\ и последовательность нахождения при нем низших магистратов
}

\author{
В. В. Дементьева ${ }^{1}$
}

${ }^{1}$ Ярославский государственный университет им. П. Г. Демидова, ул. Советская, 14 , Ярославль, 150003, Российская Федерация

DOI: 10.18255/1996-5648-2021-3-306-319

УДК 94(3)

Научная статья

Полный текст на русском языке

В статье исследуются дискуссионные вопросы о том, какие должностные позиции занимал Марк Антоний Оратор в 102-100 гг. до н. э. и в какой последовательности при нем - как носителе империя - находились квесторы Гай Норбан и Авл Габиний. Предлагается следующая историческая реконструкция: направленный в 102 г. до н. э. в должности претора в Киликию для борьбы с пиратами M. Антоний продолжил эту миссию в 101 г. уже в статусе проконсула провинции Азия. Именно как «проконсул» трактуется в статье греческое

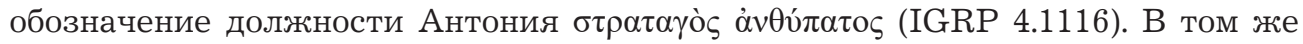
101 г. до н. э. к нему, наместнику Азии, в качестве квестора прибыл Авл Габиний (а не в 102 г. до н. э., как нередко утверждалось в историографии), который, вероятнее всего, и остался с ним в статусе проквестора на 100-й год. Определить год квестуры Гая Норбана при М. Антонии не представляется возможным, имеющиеся в научной литературе предположения о 102, 101, 100 и 99 гг. до н. э. в статье отвергаются. По мнению автора, квестура Норбана пришлась на какой-то год ранее 103 г. до н. э.; при этом датировка 113 годом до н. э. практически исключается. Больше оснований считать, что на хронологическом отрезке от пропреторских полномочий М. Антония в 113 г. до его миссии в Киликии он в какой-то год наделялся империем и имел при себе в качестве квестора Г. Норбана, но изза «молчания» источников установить этот год возможности нет.

Ключевые слова: претор; проконсул; квестура; praetor; imperium; pro praetore;

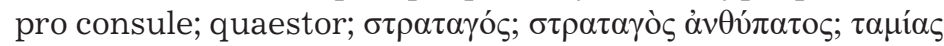

ИНФОРМАЦИЯ ОБ АВТОРАХ

Дементьева, Вера Викторовна $\mid$ E-mail:vv_dementieva@mail.ru

Доктор исторических наук, профессор, руководитель

Научно-образовательного Центра антиковедения

На рубеже II-I вв. до н. э. Марк Антоний (Marcus Antonius Orator, 143-87 гг. до н. э.) принадлежал к числу самых заметных политиков и военачальников, достигнув вершины карьеры - магистратуры цензора в 97 г. 
до н. э. Он был представителем плебейского рода, давшего видных деятелей римского государства, хотя самого Марка затмил известностью впоследствии его внук - член Второго триумвирата. Нарративная традиция сохранила о Марке Антонии ярко характеризующие его сведения - так, Цицерон восхищался им, своим учителем, как великим оратором и самым востребованным адвокатом (Cic. Brut. 37-39, 44, 57); Валерий Максим писал о нем в связи с обвинением в инцесте в период квестуры 113 г. до н. э. (Val. Max. III. 7. 9; VI. 8); Аппиан (Аpp. BC. I. 72) и Плутарх (Plut. Mar. XLIV) рисовали картину его убийства, штрихи к которой (и, в целом, к портрету М. Антония) содержатся в периохах Ливия (Liv. Per. 80), эпитомах Флора (Flor. II. 9. 13), в сочинении Веллея Патеркула (Vell. Pat. II. 22) и произведениях других авторов.

Карьера М. Антония имела решительный взлет: став в 113 г. до н. э. квестором, он получил в том же году полномочия pro praetore (обоснование этого см.: [1]), т. е. уже на нижней ступени cursus honorum выступал в роли промагистрата с империем. При относительно немалом количестве упоминаний M. Антония в источниках ряд моментов, связанных с его продвижением по должностной лестнице, являются дискуссионными, так же как вызывают разногласия у исследователей датировки нахождения при нем низших магистратов (квесторов) в то время, когда он являлся высшим магистратом (консулом или претором) или промагистратом (проконсулом или пропретором). На этих моментах и сосредоточим внимание в данной статье, а именно на определении должностного статуса Марка Антония в период 102-100 гг. до н. э. и последовательности нахождения при нем как носителе империя - названных в нарративных текстах и эпиграфическом памятнике в связке с ним квесторов Авла Габиния и Гая Норбана.

В недавнем исследовании по римской квестуре (оно же является первым монографическим трудом по ней в мировой историографии) Франсиско Пина Поло и Алехандро Диас Фернандес обратились к последнему из перечисленных выше вопросов [2, р. 214, 262, 289], однако, приводя имеющиеся точки зрения, упустили из виду таковую Френсиса Ксавье Раяна [3], не включив его статью по этому поводу в список использованной литературы (хотя привели в нем 24 других его работы) [2, р. 362]. Это также заставляет меня еще раз проанализировать имеющиеся античные свидетельства и трактовку их антиковедами.

Для начала следует обратить внимание на отражение в античной традиции и эпиграфических памятниках должностного статуса самого Марка Антония в период 102-99 гг. до н. э. (более ранний период в его карьере я уже затрагивала). Полагаю, что надо не изолированно решать вопросы о должностях М. Антония и годах нахождения квесторов А. Габиния и Г. Норбана при нем (обычно эти сюжеты рассматривались по отдельности), а в тесной связке.

Проблем с определением положения Марка Антония на служебной магистратской лестнице в 99 году до н. э. не возникает. Авл Геллий (IV. 6. 2) 
называет Марка Антония консулом в паре с Авлом Постумием, что соответствует фиксации этой пары на 99 г. до н. э. в капитолийских фрастах [4, p. 27]: $\mathrm{M}^{*}$ ANTONIVS * $\mathrm{M} * \mathrm{~F} * \mathrm{M} * \quad \mathrm{~A} * \mathrm{PO}$ *tumius ... $f \ldots n$ albinus. (CIL I.1 ${ }^{2}$. P. 27).

Имеется надпись на статуе Марка Антония, которая была посвящена богам на Делосе жителями этого острова тогда, когда он уже достиг вершин карьеры. Она найдена у портика Филиппа. В издании Inscriptions de Délos [5, р. 97] надпись (№ 1700) дана следующим образом:

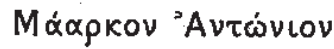

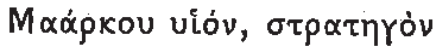

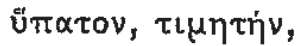

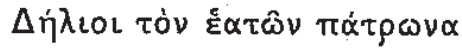

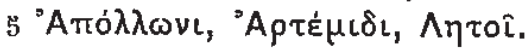

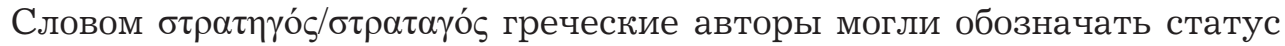
любого военачальника, даже легата [6, p. 7 (со ссылкой на Аппиана - Арр. BC. I. 91. 241; II. 29. 115)]; см. об этом [7, с. 59]. Две высшие магистратские должности с империем - консула и претора - могли передаваться на грече-

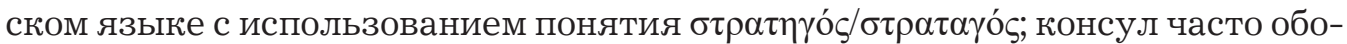

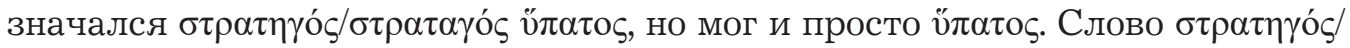

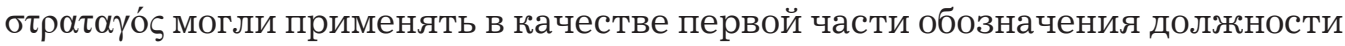

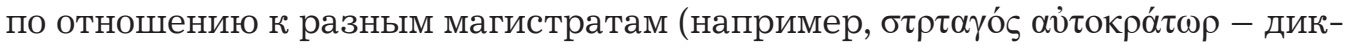

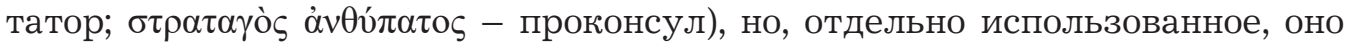
обычно обозначало претора. Проблема понимания приведенной надписи

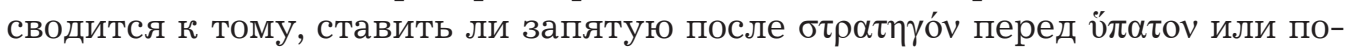
нимать эти два слова как обозначение должности консула, т. е. ставить запятую уже после данного словосочетания. В любом случае, поскольку далее упоминается цензорская магистратура Антония, то естественно считать, что в надписи речь идет, как минимум, о его консулате и цензуре, а как максимум, - перечисляются три высшие должности римского cursus honorum.

Именно как названия трех должностей понял перечисление терминов, обозначающих высшие римские магистратуры, Теофил Омолль, расставив соответствующим образом запятые в своей реконструкции текста [8, р. 133]:

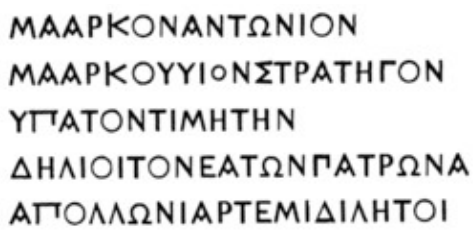

$$
\begin{aligned}
& \text { Mx́xpov 'Avтúvเov, } \\
& \text { Mxx́pos viò, orpxтnyó, }
\end{aligned}
$$

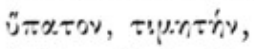

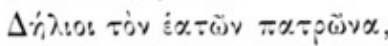

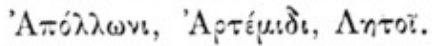

Однако Морис Олло отказался от такого понимания перечисления

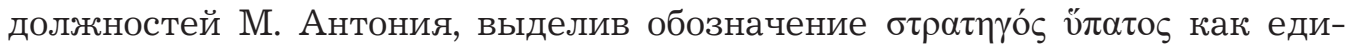
ный термин [9, р. 83-85]. П. Руссель и М. Лонэ тоже, как видим в приведенной выше реконструкции текста, последовали его примеру [5, р. 96-97].

Оба варианта имеют право на существование, но в данном случае более вероятно все же, что в надписи перечислены все три высшие должности, ко- 
Дементьева В. В.

торые занимал Марк Антоний. Поэтому воспроизведем текст надписи в таком виде:

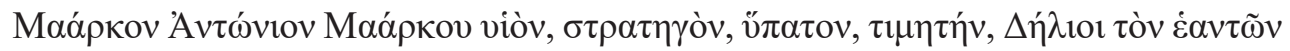

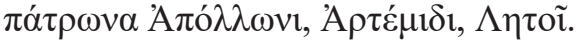

И дадим перевод:

«Делосцы \{статую\} Марка Антония, сына Марка, претора, консула, цензора, своего патрона \{посвящают\} Аполлону, Артемиде, Лето».

Как представляется, вряд ли бы при посвящении статуи и составлении на ней этой надписи ее адресанты упустили преторскую магистратуру объекта своего почитания, поскольку выполнение им в этом статусе возложенных на него задач создало ему громкое имя (он стал триумфатором). Речь идет о предоставлении ему руководства операциями на море в 102-101 гг. до н. э. [10, с. 46-55]. М. Г. Абрамзон полагает, что эта миссия была поручена Антонию под влиянием торгово-фринансовых кругов, и обосновывает, что Марк Антоний не только командовал морскими силами, но и проводил операции против пиратов в Киликии и на суше. Была ли Киликия аннексирована Марком Антонием и был ли он назначен в нее сенатом как во вновь образованную провинцию, - вопросы остаются дискуссионными. М. Г. Абрамзон не исключает того, что М. Антоний был наместником провинции Азия, которому было дано специальное назначение в «Киликию» для борьбы с пиратами [10, с. 55].

В связи с указанной миссией М. Антония особый интерес представляет еще одна надпись с его именем (IGRP 4.1116), найденная на острове Родос:

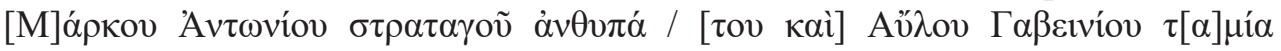

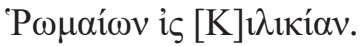

Возникает опять-таки вопрос: понимать ли словосочетание в генетиве

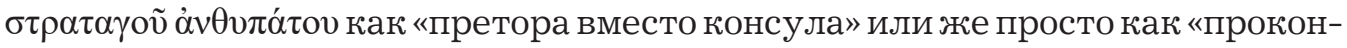
сула»? Обращение к античным авторам не проясняет ситуацию. Тит Ливий называет M. Антония претором в период его борьбы с пиратами в Киликии (Liv. Per. XLVIII): "M. Antonius praetor in Ciliciam maritimos praedones - id est piratas - persecutus est”. Цицерон же от лица M. Антония фрормулирует его тогдашнее положение как проконсульство: "tamen cum pro consule in Ciliciam proficiscens venissem Athenas" (Cic. De or. I. 82).

Е. Клебс, автор статьи о Марке Антонии в Realencyclopädie, стремясь состыковать сведения источников о претуре и проконсулате M. Антония в период его борьбы с пиратами в Киликии, пришел к выводу, что тот являлся претором с полномочиями проконсула: будучи претором, он получил назначение как проконсул в Киликию (будущую провинцию, а тогда - территорию военных действий против пиратов) [11, Sp. 2590-2591]. Однако против такой трактовки можно возразить, что для борьбы с пиратами статус претора, магистрата с империем, был более чем достаточен, никакого дополнительного проконсулата к нему добавлять для этой цели не требовалось, тем более, если Киликия не была еще провинцией как административно-территориальной единицей. Да и вообще, статус «претор вместо кон- 
сула» (praetor pro consule) вне пределов Рима выглядит несколько странно: для ведения любых дел было достаточно как преторских (магистратских) отдельных полномочий, так и проконсульских (промагистратских) - совмещать их у одного лица не было никакого резона.

Элеонор Голтц Хазар, автор биографического труда о М. Антонии-триумвире, делая экскурс о деятельности его деда, отмечает, что к 102 г. до н. э. политическая карьера Марка Антония Оратора достигла полной славы; как претор, управляющий римскими портовыми пунктами на киликийском побережье, Антоний получил первое особое командование против пиратов, чьи крепости находились вдоль этого скалистого южного побережья Малой Азии, и это командование, на ее взгляд, даже включало «власть над другими наместниками провинций». Э. Хазар так определяет должностной статус М. Антония: претор в 102 году, пропретор в 101-100 гг. до н. э., возможно, с проконсульским империем [12, р. 13-14]. Томас Роберт Броутон рассматривал М. Антония в 102 г. как претора, в 101 г. как проконсула, не называя провинцию, но отмечая его борьбу против пиратов, в 100 г. - как проконсула в Киликии [13, р. 568, 572, 576].

Ж̊ан Луи Феррари связывает М. Антония с провинцией Киликией в 102 г. до н. э. (и в том же году Г. Юлия Цезаря с провинцией Азией), а для 100 г. до н. э. в графе провинции Киликии своей таблицы ставит знак вопроса вместо имени; с провинцией же Азия приблизительно около 100 г. он связывает еще двоих - М. Плавтия Гипсея и М. Юния Силана, но точного года для каждого из них не определяет [14, р. 167, 171-173, 192].

M. Г. Абрамзон несколько раз делает глухую отсылку к приведенной мною выше надписи с о. Родос, один раз замечая, что в ней упоминается Авл Габиний, квестор Марка Антония, претора Киликии [10, с. 47], а в другом месте пишет следующее: «... в надписи IGRR, IV , 1116, посвященной родосцами капитану, который плавал с Антонием к берегам Киликии, последняя упомянута точно в своем географическом значении» [10, с. 54]. Вряд ли, конечно, квестора Авла Габиния можно назвать капитаном, во всяком случае, не ясно, из чего это следует (наличие «флотских квесторов» для меня более чем сомнительно [см: 15 , с. 54-59; 16 , с. 66-69]), но данное и другие наблюдения М. Г. Абрамзона приводят его к утверждению, что, несмотря на объявление в Lex Cnida (III. 35-37) Киликии «преторской провинцией», свидетельств существования провинциального образования не имеется. М. Г. Абрамзон подчеркивает: «Закон 102 г. до н. э., говоря об управлении восточными провинциями, называет только две из них - Македонию и Азию. Что касается Киликии, то в терминах римского права она была лишь зоной военных действий претора» [10, с. 54]. Российский антиковед, специалист по региону, таким образом, признает, что «в действительности в этот период на Востоке существовало только две ординарные римские провинции - Македония и Азия» [10, с. 49]. Отталкиваясь от этой констатации, я полагаю, что логически увязать сведения наших источников о статусе M. Антония в 102-100 гг. до н. э. можно следующим образом. В 102 г. он, находясь в должности прето- 
ра, был послан против пиратов в Киликию. На следующий, 101-й год, его преторские полномочия истекли, он мог бы быть оставлен в статусе пропретора до окончания своей миссии, которая закончилась в 101 г. до н. э., как это следует из работы М. Г. Абрамзона [10, с. 48]. И тогда на 100-й год он мог бы получить полномочия проконсула провинции Азия. Но надо учесть сведения Цицерона (проконсул, действующий в Киликии), которые заставляют меня считать, что уже на 101-й год Антоний получил полномочия проконсула провинции Азия, продолжая вести борьбу с пиратами в Киликии. Пропретор и проконсул за пределами Италии - это фактически один и тот же объем власти, - выбор, осуществлявшийся сенатом, определялся значением провинции и сложностью военной обстановки в ней. В Азию традиционно назначали проконсулов, что и обусловило - по нашим рассуждениям - смену названия должностного статуса Марка Антония (вместо пропретора проконсул). Можно привести аналогию: Гай Юлий Цезарь, отец диктатора, после занятия претуры получил назначение в провинцию Азия как проконсул, а не как пропретор.

Имеется еще один эпиграфический документ из Коринфа (CIL I². 2. $2662)^{1}$, в котором стертое имя проконсула реставрируется как Марк Антоний. Речь в нем идет о передвижении римского фрлота под командованием этого проконсула через Истм к Сиде и о подготовке фрлота другим должностным лицом - пропретором Гирром (Hirrus) в Афринах ${ }^{2}$. Хотя полной уверенности в том, что упоминаются именно интересующий нас в данном случае Марк Антоний и события рубежа самого конца II в. до н. э. (а не 70-х гг. І в. до н.э.), нет, исследователи отдают предпочтение ему. В таком случае это укрепляет нас в предположении, что если на 102 г. М. Антоний был претором, то уже на 101 г., продолжая руководить военными действиями против пиратов, он получил назначение как проконсул провинции Азия, ибо «в качестве базы и источника средств Антонию могла быть предоставлена только провинция Азия» [10, с. 48]. В конце 100 -го года он вернулся в Рим, поддерживал Мария в его борьбе против Сатурнина, но находился в разгар беспорядков (10 декабря - Арp. ВС. I. 33, см.: 13, р. 569) с войском за пределами померия, как следует из речи Цицерона в защиту Рабирия (Cic. Pro Rab. 26). M. Антоний не пересекал границу Рима потому, что ожидал триумф (о триумфе сообщает и Плутарх, как и о том, что пираты захватили дочь Антония, которую он выкупил за большую сумму - Plut. Pomp. 24) Избирательную кампанию по выборам в консулат на 99 г. до н. э. М. Антоний, в таком случае, вел заочно.

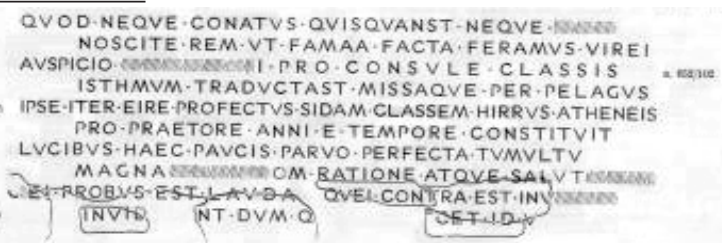

${ }^{2}$ Т. Р. Броутон определял статус Гирра как legatus pro praetore для 102 и 101 гг. до н. э., предположив, что личное и родовое имя Гирра были Гай Луцилий (C. Lucilius). См.: [13, p. 569, 573]. 


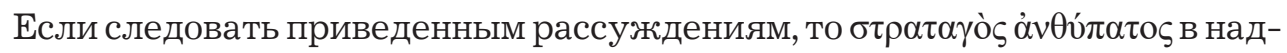
писи с острова Родос (IGRP 4.1116) нужно понимать как «проконсул» и относить ее к 101 г. до н. э., поскольку для 102 г. Марк Антоний должен бы быть

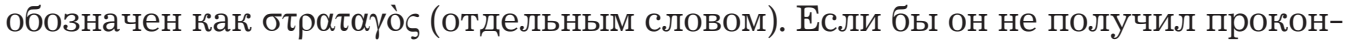
сульские полномочия на 101-й г., то при продлении ему империя на этот год для действиий против пиратов на территории Киликии, еще бывшей не ординарной провинцией (административно-территориальным образованием), а преторской провинцией (в значении «сфера деятельности претора»), его ста-

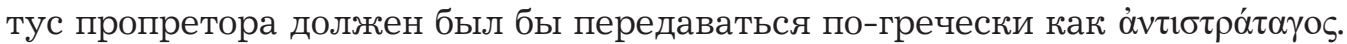

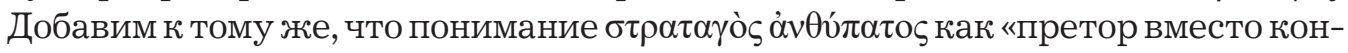
сула» теоретически могло бы соответствовать положению М. Антония в 102 г. до н. э., если бы борьба с пиратами в Киликии требовала консульского/проконсульского статуса, который - в отличие от управления провинцией Азия год или два спустя - совершенно не требовался. Быть назначенным как praetor pro consule в провинцию Азия (даже если допустить, что такой статус давался претору вне Италии) в 102 г. до н. э. он не мог, там в том году, если следовать Ж по его мнению [14, p. 192]). Для 100 г. до н. э. такое понимание должности в греческом обозначении (претор вместо консула) гипотетически было бы возможно в том случае, если бы именно в этом году М. Антоний был претором, но это не соответствует его избранию претором на 102 г. до н. э.

Представив наиболее вероятный, на мой взгляд, порядок занятия должностей с империем Марком Антонием на рубеже II-I в. до н. э., перейду к запутанной ситуации с его квесторами. Историкам известны только два имени квесторов этого времени, связанных с ним, - Авла Габиния (A. Gabinius) и Гая Норбана (C. Norbanus), возможно имевшего когнмен Бальб (Balbus). Авл Габиний, как уже было сказано, назван в родосской надписи (IGRP 4.1116) в должности квестора при Марке Антонии (греческое тані́ quaestor). Гай Норбан отмечен Цицероном - как бывший квестором М. Антония - в трактате «Об ораторе» (Cic. De oratore. II. 202) при описании защиты Антонием Норбана на суде через годы их совместной службы (в 95 или 94 г. до н. э., Э. Бэдиан наиболее вероятной датой считал начало 95 года [17, p. 320; 18, c. 166]): "hic Sulpicius, vere hercle, inquit, Antoni, ista commemoras.... ut illud initio, quod tibi unum ad ignoscendum homines dabant, tenuisti, te pro homine pernecessario, quaestore tuo". В 83 г. до н. э. Норбан достигнет консульской должности, о чем известно из разных источников (напр., капитолийских фаст - CIL I.12. P. 27), так же как и о том, при каких обстоятельствах завершилась его жизнь: он был внесен в первый сулланский проскрипционный список, бежал на о. Родос, где и покончил с собой (Oros. V. 21. 3; App. BC. I. 91). Но о его квестуре на рубеже II-I в. до н. э. точных хронологических привязок в источниках нет.

Фридрих Зобек, автор первой систематизации и хронологического упорядочения имен римских квесторов, в своей диссертации отнес деятельность Авла Габиния в этом статусе к 74 г. до н. э. [19, S. 41], посчитав, что упомяну- 
тый в надписи М. Антоний - Марк Антоний Критский, сын Марка Антония Оратора. Квестуру же Г. Норбана Ф. Зобек продатировал так: 102 или 99 г. до н. э. [19, S. 25-26]. При этом Ф. Зобек посчитал Г. Норбана плебейским трибуном 105 г. до н. э. и, полагая, что обычно плебейский трибунат следовал после квестуры, определил противоречащей такой практике датировку квесторской должности Норбана 102 годом. Против датировки квестуры Норбана перед 105 г. до н. э. он привел следующий аргумент: в этом случае интервал с его претурой (88 г. до н. э.) был бы слишком большим, к тому же, как он считал, Марк Антоний не мог иметь соответствующую должность, чтобы при нем был квестор. Впоследствии Фридрих Мюнцер определил годом плебейского трибуната Норбана 103 г. до н. э. [20, S. 224], а при датировке его квестуры склонился к 102 году, аргументируя это тем, что Норбан через два десятка лет спасался на Родосе от проскрипций Суллы потому, что именно там мог найти защиту, т. к. родосцы в первую очередь поддерживали мероприятия по борьбе с пиратами Марка Антония, при котором в то время, по предположению Ф. Мюнцера, и был квестором Г. Норбан [20, S. 226]. Обоснование, данное Ф. Мюнцером, конечно, довольно шаткое, но исследователям приходится - в условиях ситуации с дефицитом источников - искать хотя бы слабые зацепки и приводить косвенные доказательства.

Вслед за Ф. Мюнцером год плебейского трибуната Г. Норбана как 103 г. до н. э. признал и Т. Р. Броутон [13, р. 563-564], согласившийся и со 102 г. как временем квестуры Норбана [13, p. 569; 21, р. 595], хотя не отвергал и возможность таковой в 101 г. [13, p. 566, n. 7] и в 99 г. [22, р. 149]. Квестуру А. Габиния Т. Р. Броутон поместил в 101 г. до н. э. [13, р. 572].

Однако другие историки стали отвергать 102 г. как год квестуры Гая Норбана, на том основании, что Лили Росс Тейлор сделала вывод, что уже с конца II в. до н. э. квесторам 5 декабря вручали магистратскую власть [23] (хотя, заметим, полной уверенности в этом не может быть). Получалось, что Г. Норбан только 9 декабря 103 г. должен был сложить полномочия плебейского трибуна, а в качестве квестора 102 г. обязан был вступить должность 5-го декабря. Сама Л. Р. Тейлор отнесла квестуру Г. Норбана к 101 году $[23$, p. 21, n. 3].

Эрих Грюэн исключил датировку квестуры Норбана 101 г. до н. э. [24, р. 105-107], отнеся к этому году квестуру А. Габиния и посчитав, что квестор должен был оставаться при высшем магистрате/промагистрате на протяжении всего времени его пребывания в провинции. В трактовке Э. Грюэна получалось, что в течение 102-100 гг., следуя данной практике, Габиний находился в Киликии вместе с Антонием. Однако такая практика пребывания квесторов при своих командующих в провинции как норма не подтверждается источниками [см. об этом: 25, с. 17-18]. Приведенные Э. Грюэном примеры не исчерпывают разнообразие ситуаций, противоположные примеры имеются тоже. Для квестуры Норбана Э. Грюэн считал «очевидной альтернативой» 99 г. до н. э., год консулата М. Антония. 
Специальное внимание Гаю Норбану уделил Эрнст Бэдиан, опубликовавший с промежутком в четверть века две статьи, касавшиеся его деятельности [17 (перевод на русский язык - 18), 26], во второй из них английский исследователь утверждал, что Норбан был квестором М. Антония в 101 и 100 гг., до н., сменив на этом посту А. Габиния, квестора, по его мнению, 102 г. до н. э. Э. Бэдиан усматривал необычность cursus honorum Норбана, допуская, что его трибунат мог предшествовать квестуре, поддерживал $\Phi$. Мюнцера в его предположении, что выбор Родоса в конце жизни Норбана может быть объяснен связями, возникшими во время его квестуры. При этом Э. Бэдиан полагал, что наложение по времени полномочий трибуна 103 г. и квестора 102 г. заставляет отнести квестуру Норбана к 101 году. Э. Бэдиан писал статью 1983 года в русле полемики с Э. Грюэном, в числе его контраргументов было наблюдение, что в период от конца Ганнибалловой войны и после Суллы от квесторов не ожидали, что они останутся с командующими до возвращения в Рим последних, они оставались с ними на год, самое большее - два, остальное не было нормальной практикой. Э. Бэдиан обращался и к фигуре интересующего нас Авла Габиния в статье, посвященной другому Габинию, консулу 58 г. до н. э. Габиния, квестора 102 года (как он считал), он идентифицировал с легатом 89 г. до н. э. в период Союзнической войны [27, p. 87-88]. Замечу, что автор монографии о легатах Римской республики Бернхард Шлойсснер отнес квестуру Габиния-легата к 101 г. до н. э. [28, S. 228], следуя, очевидно, Т. Р. Броутону.

Френсис Ксавье Раян в статье 1995 г. [3, р. 145-150] призвал отказаться от альтернативы в датировке квестуры Г. Норбана - 101-й или 99-й год. Он отметил, что, хотя ученые приняли 103-й год как наиболее вероятный год трибуната Норбана, этот консенсус не помог в разрешении спора по поводу даты его квестуры, и подчеркнул, что нет сильного аргумента в пользу 101-го или 99-го г.: cursus Гракхов показывает, что квестура была учреждена как должность, уступающая трибунату [3, p. 146]. Поэтому $\Phi$. К. Раян считал необходимым определять год квестуры Норбана до года его трибуната. Он обратил внимание на то, что М. Антоний, при котором Норбан отмечен как квестор, обладал империем, будучи еще квестором pro paetore, и в таком качестве мог иметь под своим началом квестора [3, p. 148-149]. При этом Ф. К. Раян колебался, получил ли империй Антоний как квестор в 113 г. на короткое время или уже как проквестор в 112 г. до н. э. Поскольку Норбан стал консулом в 83 г. до н. э., то, отметил Ф. К. Раян, если его квесторство за 29 лет до этого кажется мало правдоподобным (хотя, замечает он, следует помнить, что квестору в этот период могло быть меньше 30 лет), то можно предложить еще один вариант: М. Антоний мог получить еще одно командование в качестве пропретора в промежуток между его квестурой/проквестурой в 113/112 гг. и его претурой в 102 году. Если М. Антоний, продолжал свою мысль $\Phi$. К. Раян, достойно выступил при первом наделении его пропреторским империем, то сенат мог поручить ему другое военное командование, особенно в те годы, когда трудно было найти хоро- 
ших командиров. На взгляд Ф. К. Раяна, гораздо предпочтительнее полагать возможность повторение статуса пропретора у Антония, чем предполагать, что Норбан занимал квестуру после трибуната. Ф. К. Раян допускал также, что Норбан мог быть квестором на 105-й год и служить легатом М. Антония в 102-100 гг., а с этого поста получить статус pro quaestore. В целом вывод Ф. К. Раяна о том, что исследователям в поисках года квестуры Норбана не надо зацикливаться на периоде 102-100 гг. до н. э., когда Марк Антоний вел борьбу с пиратами в Киликии, представляется мне оправданным.

К сожалению, на эту работу $\Phi . К$. Раяна не обратили внимание авторы монографии 2019 г. о римской квестуре Ф. Пина Поло и А. Диас Фернандес, которые взвешивали возможные варианты датировки квестур Г. Норбана и А. Габиния в рамках 102-99 гг. до н. э. и никак не отреагировали на позицию и аргументы своего предшественника. Написав, что «дать четкий ответ по этой проблеме непросто», они присоединились к точке зрения Э. Грюэна о том, что Габиний был квестором М. Антония в 102 г. и оставался с ним в 101 и 100 гг. (они уточнили при этом, что два последних года из этих трех он уже был не квестором, а проквестором). Квестуру же Норбана они посчитали «разумным» отнести к 99 г., году консульства M. Антония [2, р. 262, 289]. Ф. Пина Поло и А. Диас Фернандес скептически высказались о точке зрения $\Phi$. Мюнцера и Э. Бэдиана по поводу обстоятельств нахождения Норбана на Родосе.

Изложив представленные в историографии разнообразные вариации исследовательских умозаключений, выстроим свою логику подхода к решению вопроса о последовательности нахождения двух известных по именам квесторов при Марке Антонии Ораторе. Самую важную информацию по данному поводу содержит надпись с о. Родос (IGRP 4.1116), датировка которой, как было показано, зависит от того, как понимать должность Анто-

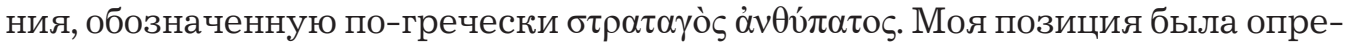
делена - это должность проконсула, наибольшая вероятность получения которой Марком Антонием в рассматриваемом трехлетии 102-100 гг. до н. э. приходится на 101-й год и продления на 100-й. И отсюда вытекает, что именно А. Габиния, упомянутого в родосской надписи вместе с М. Антонием, надо считать квестором 101-го года (в 100-м году в таком случае он мог быть проквестором, но не квестором), а не Г. Норбана. Куда же тогда хронологически отнести квестуру Норбана? Принимая во внимание исследовательский консенсус о том, что его плебейский трибунат пришелся на 103 г. до н. э., и сложность состыковки трибуната с квестурой следующего года из-за наложения сроков завершения одной должности и начала второй, а также нарушение практиковавшейся последовательности занятия квесторской и трибунской должностей, приходим к выводу, что 102-й год как год квестуры Норбана выглядит практически нереальным. Конечно, наблюдения в историографии о сроках сложения и начала полномочий в изучаемое время могут быть неточными, а плебейский трибунат не являлся ступенькой собственно магистратского cursus honorum, но тем не менее авторитет плебейского трибуна- 
та в Риме был выше квестуры и обратная последовательность в их занятии выглядит проблематично. По той же причине сомнительно относить квестуру Норбана и к 99 г. до н. э. - следует в этом отношении согласиться с Ф. К. Раяном. Из известных нам лет наделения империем Марка Антония Оратора, в должностной связке с которым в роли квестора мог выступить Г. Норбан, остается 113 г. до н. э. Но, как было обосновано [см.: 1], Антоний, будучи сам в том году квестором, на какую-то часть этого года получил статус quaestor pro praetore. И в таком случае это произошло уже тогда, когда он находился в провинции Азия, следовательно, другого квестора, кроме него, там не было, и маловероятно, что ему могли откуда-то прислать для финансовых и других квесторских дел именно квестора (все избранные на тот год квесторы уже выполняли задачи в рамках своей сферы деятельности), а не, допустим, легата. Разве что Норбану даны были полномочия legatus pro quaestore, но магистратуру квестора он не успел бы занять в том году. Поскольку других вариантов для Норбана быть квестором в связке с М. Антонием - носителем империя - не обнаруживается, остается признать, как это сделал Ф. К. Раян, что Г. Норбан был квестором за пределами Италии при М. Антонии в какой-то год из тех лет (после 113 г. и до 102 г. до н. э.), для которых в источниках о Марке Антонии Ораторе нет никаких упоминаний, но в которые (какие-то/какой-то из них) он вполне мог быть наделен империем. В отличие от Э. Грюэна, который тоже относил квестуру Габиния к 101 г. до н. э., я не считаю его квестором и в 102 г., как это делал он. Квесторское должностное место этого 102 года при преторе M. Антонии, если оно ему было выделено, в моей логике рассуждений остается для историков «вакантным».

Таким образом, в предлагаемой исторической реконструкции М. Антоний Оратор в 102 г. до н. э. в статусе римского претора был отправлен в Киликию бороться с пиратами; эту миссию он продолжил в 101 г., но уже в статусе проконсула провинции Азия (которая была источником средств для выполнения этой миссии); назначение именно в нее Антония тем более было оправдано, поскольку она была ему знакома, - он был в ней pro praetore в 113 году. Статус Антония как проконсула (а не как пропретора) был обусловлен тем, что уже сложилась традиция в эту провинцию, как важную во многих отношениях, в том числе и военном, направлять проконсулов. В 101 г. к нему, как к наместнику Азии, в качестве квестора прибыл Авл Габиний, который, вероятно, и остался с ним в качестве проквестора на 100-й год. Определить год квестуры Гая Норбана при М. Антонии не представляется возможным; по всей видимости, она пришлась на какой-то год ранее 103 г. до н. э. Так как в имеющихся источниках перед киликийской миссией Антония отражен только один год, когда он обладал империем, - 113 г. до н. э., но сам был послан в том году в должности квестора в провинцию Азия и получил пропреторские полномочия только на какую-то часть года, это делает практически невероятным направление к нему другого квестора, а не легата и не промагистрата для исполнения квесторских фрункций. Тем самым остается считать, что на хронологическом отрезке от пропреторских пол- 
номочий М. Антония в 113 г. до н. э. до его миссии в Киликии, начавшейся в 102 г. до н. э., он в какой-то, как минимум, один год наделялся империем и имел при себе в качестве квестора Г. Норбана, но из-за «молчания» источников точно определить данный исторический момент не представляется возможным.

\section{Ссылки}

1. Дементьева В. В. Делосская надпись с именем Марка Антония (ID.2 1603): к вопросу о греческой терминологии обозначения проквесторов с преторскими полномочиями // TRIVMVIRATVS OPTIMORVM / под ред. О. Л. Габелко и А. В. Мосолкина: СПб.: РГПУ им. А. И. Герцена, 2021 (в печати).

2. Pina Polo F., Díaz Fernández A. The Quaestorship in the Roman Republic. Berlin/Boston: Klio Beihefte. De Gruyter, 2019. 395 p.

3. Ryan F. X. The Quaestorship of Norbanus // C\&M. 1995. Vol. 46. P. 145-150.

4. Fasti Capitolini // CIL I.12. Berolini, 1893. P. 16-29.

5. Inscriptions de Délos / Published by P. Roussel and M. Launey. Paris, 1937. 350 p.

6. Mason H. J. Greek Terms for Roman Institutions. A Lexicon and Analysis. Toronto, 1974. XXIII + 207 p.

7. Дементьева В. В. Родосская надпись (SIG3 745): что связывало грека Поликла с римскими должностными лицами?// Lumen intellectus [Свет разума]. Памяти Ии Леонидовны Маяк: сборник статей Научно-образовательного центра антиковедения ЯрГУ им. П. Г. Демидова /отв. ред. В. В. Дементьева. Ярославль: Филигрань, 2019. С. $53-67$.

8. Homolle Th. Les Romains à Délos // BCH. 1884. Vol. 8. P. 75-158.

9. Holleaux M. Textes Gréco-Romains // REA 1917. T. XIX, № 1. P. 77-97.

10. Абрамзон М. Г. Римское владычество на Востоке: Рим и Киликия (II в. до н. э. - 74 г. н. э.). СПб.: Акра; Гуманитарная Академия. (Серия "Studia classica"), 2005. 256 с.

11. Klebs E. Antonius (28) // RE. 1894. T. I. 2. Sp. 2590-2594.

12. Huzar E. G. Mark Antony. A Biography. Minneapolis: University of Minnesota Press, 1978. $350 \mathrm{p}$.

13. Broughton T. R. S. The Magistrates of the Roman Republic. Vol. I. Atlanta, Georgia, 1986. XIX+588 p.

14. Ferrary J.-L. Les gouverneurs des provinces romaines d’Asie Mineure (Asie et Cilicie), depuis l’organization de la province d’Asie Jusqu'à la première guerre de Mithridate (126-88 av. J.-C.). // Chiron. 2000. Bd. 30. P. 161-193.

15. Дементьева В. В. Римская квестура в III в. до н. э.: увеличение числа магистратов и их новые функции // Вестник древней истории. 2011. № 3. С. 53-70.

16. Дементьева В. В. Гавань Ostia / Portus: морские ворота Рима в процессе освоения и преобразования пространства // Maria nostra: Mope в истории европейской цивилизации от Античности до Нового времени: коллективная монография / под ред. А. Н. Маслова и А. В. Махлаюка. Нижний Новгород: Изд-во Нижегородского госуниверситета, 2020. Гл. 3. С. 64-83. 
17. Badian E. Caepio and Norbanus: Notes on the Decade 100-90 B.C. // Historia. 1957. Bd. 6. P. 318-346.

18. Бэдиан Э. Цепион и Норбан (заметки о десятилетии 100-90 гг. до н. э.) / пер. А. Б. Егорова // Studia historica. M., 2010. Вып. Х. С. 162-207.

19. Sobeck F. Die Quästoren der Römischen Republik. Trebnitz, 1909. 95 S.

20. Münzer F. Norbanus // Hermes. Zeitschrift für Classische Phililogie. 1932. Bd. 67. S. 220-236. URL: https://gallica.bnf.fr/ark:/12148/bpt6k55242p/f228.item.langDE (дата обращения: 03.05 2021).

21. Broughton T. R. S. The Magistrates of the Roman Republic. Vol. II. Atlanta, Georgia, 1986. IX+647 p.

22. Broughton T. R. S. The Magistrates of the Roman Republic. Vol. III. Supplement. Atlanta, Georgia, 1986. IX+294 p.

23. Taylor L. R. Magistrates of 55 B.C. in Cicero's Pro Plancio and Catullus 52 // Athenaeum. New Series. 1964. Vol. 42. (1-4). P. 12-28.

24. Gruen E. S. The Quaestorship of Norbanus // Classical Philology. 1966. Vol. 61. P. 105-107.

25. Дементьева В. В. Квесторские provinciae за пределами Италии // Вестник РГГУ (Российского государственного гуманитарного университета). Studia classica et mediaevalia. 8. 2011. № 14 (76)/11. C. 11-27.

26. Badian E. The Silence of Norbanus: A Note on Provincial Quaestors under the Republic // AJPh. 1983. Vol. 104. P. 156-171.

27. Badian E. The Early Career of A. Gabinius (Cos. 58 B.C.) // Philologus. 1959. Vol. 103. P. $87-99$.

28. Schleußner B. Die Legaten der römischen Republik. Decem legati und ständige Hilfsgesandte. München, 1978. 255 S.

\section{Список сокращений}

AJPh - American journal of philology. Baltimore (Md.): Johns Hopkins University Pr.

$\mathrm{BCH}$ - Bulletin de correspondance hellénique. Athènes: École française d'Athènes; Paris: de Boccard.

C\&M - Classica et mediaevalia.

CIL - Corpus Inscriptionum Latinarum.

ID - Inscriptions de Délos. Published by P. Roussel and M. Launey. Paris, 1937.

IGRP - Inscriptiones Graecae ad res Romanas pertinentes. R. Cagnat et al. (eds). Paris, 1906-1927.

RE - Paulys Realencyclopädie der classischen Altertumswissenschaft.

REA - Revue des études anciennes. Pessac: Université Michel de Montaigne, Maison de l'archéologie. 